\title{
The Cultural Dimensions of the Vietnamese Private Entrepreneurship
}

\section{Vuong Quan Hoang and Tran Tri Dung}

In this essay, we explore cultural impacts on the private entrepreneurship in the post-Doi Moi Vietnam. Some important aspects of the traditional cultural values of the Vietnamese society are explored in conjunction with the socio-economic changes over the past two decades. Traditional cultural values continue to have strong impacts on the Vietnamese society, and to a large extent to adversely affect the entrepreneurial spirit of the community. Typical constraints private entrepreneurs face may have roots in the cultural facet as legacy of the Confucian society, such as relationship-based bank credit. Low quality business education is both victim and culprit of the long-standing tradition that looks down on the role of private entrepreneurship in the country.

JEL Classifications: A14, E00, L14, L26, M21, P20, P31, Z10, Z13

Keywords: Culture; Confucian values; Confucianism; Entrepreneurship; Market economy; Rent seeking; Vietnam

\author{
CEB Working Paper $N^{\circ} 09 / 027$ \\ July 2009
}

Université Libre de Bruxelles - Solvay Brussels School of Economics and Management Centre Emile Bernheim

ULB CP 145/01 50, avenue F.D. Roosevelt 1050 Brussels - BELGIUM

e-mail: ceb@admin.ulb.ac.be Tel. : +32 (0)2/650.48.64 Fax : +32 (0)2/650.41.88 


\title{
The Cultural Dimensions of the Vietnamese Private Entrepreneurship
}

\author{
Vuong Quan Hoang ${ }^{1}$ \\ Centre Emile Bernheim, SBS-EM \\ Université Libre de Bruxelles \\ ULB CP 145/01 Ave. F.D. Roosevelt, 50, Brussels 1050, Belgium \\ Tran Tri Dung \\ Dan Houtte, Vuong \& Partners \\ 6/80 Le Trong Tan, Thanh Xuan District, Hanoi, Vietnam
}

Centre Emile Bernheim's Working Papers No. WP-CEB-09-027

First Draft

July 15, 2009

\begin{abstract}
:
In this essay, we explore cultural impacts on the private entrepreneurship in the post-Doi Moi Vietnam. Some important aspects of the traditional cultural values of the Vietnamese society are explored in conjunction with the socio-economic changes over the past two decades. Traditional cultural values continue to have strong impacts on the Vietnamese society, and to a large extent to adversely affect the entrepreneurial spirit of the community. Typical constraints private entrepreneurs face may have roots in the cultural facet as legacy of the Confucian society, such as relationship-based bank credit. Low quality business education is both victim and culprit of the long-standing tradition that looks down on the role of private entrepreneurship in the country.

Keywords: $\quad$ Culture; Confucian values; Confucianism; Entrepreneurship; Market economy; Rent seeking; Vietnam
\end{abstract}

JEL classifications: $\quad$ A14, E00, L14, L26, M21, P20, P31, Z10, Z13

\footnotetext{
${ }^{1}$ Corresponding author; e-mail: qvuong@ulb.ac.be or hoangvq@empirics.net.
} 


\section{Introduction}

This article serves to be an essay on the cultural impacts on the private entrepreneurship in the post-Doi Moi Vietnam. Some important aspects of the traditional cultural values of the Vietnamese society are explored in conjunction with the socio-economic changes over the past two decades.

In the academic circle in the world, entrepreneurship has enjoyed a voluminous literature contributed by many scholars in economics, sociology, anthropology, business management and political sciences, since the middle of the $20^{\text {th }}$ century. The research line of entrepreneurship has received a huge attention from the worldwide economists' community, especially after the seminal work in 1934, by Joseph Schumpeter, The Theory of Economic Development. In his work, Schumpeter placed entrepreneurship in a major theoretical framework to treat the progress of human society and economic growth. Since the work of Schumpeter, there has been a major shift in perception of economists. Entrepreneurs could now be considered a crucial factor in contributing to economic growth by taking up opportunities, creating business and making innovation happen. By doing all these, entrepreneurship processes shift the economy out of an equilibrium state, while creating new states (Greenfield and Strickson 1981).

Stevenson and Jarillo (1990) provide us with a decent review of worldwide studies on entrepreneurship that they call 'the plethora.' Three main streams of research are presented. The first area of literature is concerned with the consideration of what happen when entrepreneurs act; or in other words, they study the net effect upon the general economic system of the actions performed by entrepreneurs. Major scholars that contributed significantly to this area are, inter alia, Richard Cantillo (who first coined the term 'entrepreneur'), Jean Baptiste Say, Adam Smith and Joseph Schumpeter.

The second batch of literature on entrepreneurship is concerned with why entrepreneurs act; or what the causes of entrepreneurship are. Naturally, entrepreneurs themselves have now become the subjects of interest to economist. If the first area of literature draws attention mainly from economists, this attracts a large number of sociologists, psychologists and anthropologists as well. The first level of inquiry into the causes of entrepreneurial behavior, according to Stenvenson and Jarillo (1990), conceptualizes entrepreneurship as a psychological characteristic of individuals: 
creativity, daring and aggressiveness. The second level of inquiry conceptualizes

entrepreneurship as a social role that may be enacted by individuals in different social positions.

The third area of literature on entrepreneurship is concerned with the how of entrepreneurship; that is, studying managerial practices performed by entrepreneurs. This has proved to be a vast literature, studying from the startup of small businesses, venture capital, entrepreneurial management, etc. to the forming of strategy in entrepreneurial firms. The sub-domains of this research line consist of: (a) life cycles to become mature companies; and, (b) finding predictors for success of entrepreneurial firms.

Other scholarly research works, which also provide us with a great account of literature surveys as well as insights derived from hypothesis tests looking into the nature of entrepreneurial firms across cultural settings and countries, are, inter alia, Stopford and Baden-Fuller (1994); Lumpkin and Dess (1996); Baker et al. (2005).

In light of the above, in the economy in transition of Vietnam, the importance of entrepreneurs would be further highlighted with the jobs they create, the risk they take and the investment (physical and social capital) they put in their entrepreneurial endeavors.

In this paper, we aim to communicate over a set of cultural dimensions that have become increasingly influential in the economy, in parallel with the phenomenal resurgence of private entrepreneurship in Vietnam, that is, the existence of a large number of newborn SMEs, a typical symbol of private entrepreneurship as characterized by the relevant literature. By this, we would clearly be emphasizing the cultural aspects of the entrepreneurial environment and opportunities available in Vietnam, together with reasonable qualitative assessment of the current situation of the private entrepreneurship in this emerging market economy, in a mixture with the long-lasting deeply rooted cultural dimensions in the mind of the public, businesspeople and policy makers.

In this essay, we clearly advocate the different perception from pure economic growth advocacy, which explores the complexity of the relationship between cultural values inherent to the society, including entrepreneurs, and the economic behaviors, especially in their rent-seeking strategy in conjunction with economic performance. The analysis will elaborate on the relationship between cultural facets of Vietnam and entrepreneurs' determination of business conducting, under the strong influence of Confucianism (儒家) imported from China, centuries ago. 


\section{The Vietnamese Private Entrepreneurship and Economic Development}

The Vietnamese nationwide economic reform (known as Doi Moi, started in 1986), together with its highly praised economic achievements (see Vuong et al. 2008, Vuong and Pham 2009), has brought about a phenomenal transition to a market-oriented model, in which entrepreneurship has broadly become a universal modality for people wishing to become gloriously rich.

Entrepreneurial spirit and many entrepreneurial attempts by hundreds of thousands of ordinary people in Vietnam has cultivated in this emerging economy a new wave of economic growth taking advantages of varieties of existing and future opportunities. Up until March 2009, in Vietnam there have been approximately 349,000 small- and medium-sized enterprises (SME), who are basically entrepreneurs, as usually perceived by economists. When seeking ways to attain the business freedom and self-reliance for themselves, Vietnamese entrepreneurs have helped change both themselves into more professional businesspeople and the economy into a much more business-oriented model.

The economic and cultural values that the Vietnamese economy has gained from these entrepreneurship processes are apparently enormous. In brief, it is agreeable that entrepreneurship has changed the economic situation to a large extent, as discussed in Vuong (2007). Per capita real GDP of Vietnam, as reported by the General Statistics Office, have increased from US\$202 in 1986 -- when Doi Moi started -- to US\$361 in 1998. In 1999, a new Enterprise Law was passed, which relaxed a bunch of regulations for business start-up (see Figure 1). And this law was recognized as the key factor that helps send the number of new enterprise higher. Per capita GDP in Vietnam kept rising to US\$416, 835 and 1030 at the end of 2001, 2007 and 2008, respectively.

Today's private SME sector contributes approximately $40 \%$ of GDP to the economy, as reported in official statistics. As to the industrial output, private entrepreneurship's contribution in Vietnam has increase from $24.6 \%$ in 2000 , to $27.5 \%, 37.0 \%$ in 2003 and 2005 , respectively. ${ }^{2}$ It is

\footnotetext{
${ }^{2}$ Economists have, for long, expressed their opinions that the true level of contribution by SMEs would likely be higher, largely because the SME sector's output has never been fully reported due to a high volume of informal economic activities and weak statistical capability.
} 
not surprising that entrepreneurship economy has also created the majority of new jobs for the country.

Given the critical importance of entrepreneurship, the Government of Vietnam, since 1998, has set forth a strategic goal of promoting the number of domestic enterprises to half a million by 2010 - a goal that is equivalent to facilitating hundreds of thousands of people to become entrepreneurs or turning existing entrepreneurs running household business to corporate people, very much in line with Stopford and Baden-Fuller's argument (1994).

In 2006, the Government reiterated this roadmap for further developing Vietnam's private SME sector, with the Prime Minister's Decision No. 236/2006/QD-TTg dated Oct. 23, 2006 on a 5year SME development plan, which aimed to increase the number of private SMEs to 320,000.

While the importance of entrepreneurship in Vietnam has been undisputable, it seems that the dearth of academic literature has not shown an equivalent level of attention within the academic circle. Serious studies on entrepreneurship in Vietnam were mostly contributed by foreign scholars (e.g. Ronnås 1992; Ronnås and Ramamurthy 2001). And recently, securities firms, listed companies and stock markets become the main locus for studies, the number of studies on entrepreneurship appeared to subside.

Figure 1. The population of private enterprises in Vietnam (1990-2010)

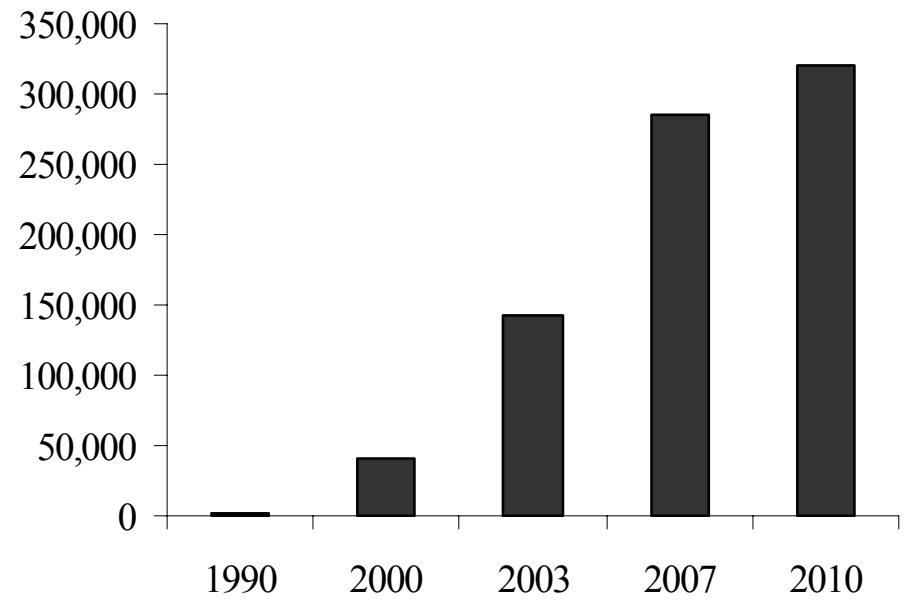

In Vuong (2007), entrepreneurship has been singled out as the most important driver for the omnipresent growth of the economy. However, the process of economic development and growth 
is attributed mainly to the liberalizing of the workforce and market economic activities, which provide entrepreneurs with commercial incentives to perform better economically, rather than a real shift to become highly competitive and with significant innovations of the business methods and attitudes.

The latter has since proved to be of much greater importance than the generally accepted Ricardian framework, which tends to attribute a faster pace of economic growth to more inputs and better technology, as later promoted by more mathematically inclined economist like Solow. In fact, we advocate the framework of Adam Smith, set forth in his The Wealth of Nations (1776), which specifies that exploiting opportunities, current or predicted to appear in the future, together with self-motivation of commercial benefits would lead to proactive economic activities with self-reliance, trade, risk taking, altogether forming entrepreneurship in its genuine meaning.

\section{The Cultural Roots of Confucianism in the Vietnamese Entrepreneurship}

The socio-economic settings play a critical role in defining the targets that an economy pursues and the road that it takes to achieve them. In light of this, although being a member of ASEAN, geometrically defined as a Southeast Asian country, Vietnam has for long been tied to the Chinese cultural roots, with over a thousand years under the Chinese ruling and the rest under strong economic and cultural dominance. As a result, the country has naturally been steeped in the Chinese-originated Confucianism, and until the French army's invasion, then the whole country was put under the austerity of the French in 1884, Confucian values still served as guiding thought for governing the society, from Confucian-style examination, official designation, government organization and society structure, etc. which were almost identical to a typical Confucian Chinese society.

Confucianism $^{3}$ is a Chinese ethical and philosophical system developed from the classic teachings of the Chinese philosopher Confucius. ${ }^{4}$ This spiritual system concentrates on human morality and behaviors in a hierarchical society and has for more than two thousand years institutionalized its set of cultural values on East Asian countries, namely China, Japan, Korea and Vietnam. It is a complex system of moral, social, political, philosophical, and quasi-religious

\footnotetext{
${ }^{3}$ Rújiā 儒家

${ }^{4}$ Kŏng zì (孔子, 551-479 B.C.)
} 
thought that has had tremendous influence on the culture and history of East Asia. The Han Dynasty ${ }^{5}$ of China was the first that promoted Confucian values Confucianism, when Han Wudi (141-86 B.C.) decided to choose Confucianism for use as a political system to govern the Chinese state.

Vietnam had been under Chinese invasion throughout the first thousand years of its history, until the defeat of Nan Han navy troops by Ngo Quyen, a feudalist general in 938 AD, whose coronation as the first king of sovereignty followed in 939 AD. Then, Vietnam entered the period of independent sovereignty from 939 till 1884. However, during this period of independence (nearly 1,000 years), it was invaded frequently by different Chinese Dynasties, until late $19^{\text {th }}$ century when French troops and the Qing Dynasty agreed to put Tonkin (North Vietnam) under the French austerity in 1885. Since the Han Dynasty, China already became a well-established civilization, and the first country to see weekly and monthly markets spread across the country. It had the economic and military power that led to its imposition of cultural values and Confucianism on Vietnam, the much smaller and less developed neighboring country.

The Confucian values built over a thousand years, through formal Confucian-style education, social events, family teachings, have become deeply rooted in the mind of almost everyone in the society regardless of whether a person realizes the existence of them or not. We need to look into essence of the doctrine to see connection between of values promoted by Confucianism and the nature of entrepreneurship. Their distance and perhaps contradictions would be very helpful in understanding the why and how of cultural influences on the process of the Vietnamese private entrepreneurial processes.

\subsection{What is it? Is it all gone?}

Since the Confucian doctrine has been a major school of thought in the world and appeared very early in the history of the human beings, there have been many research studies on Confucianism in different individual and interdisciplinary branches of social sciences: sociology, philosophy, government studies, etc. Studies on the influences of the Confucian doctrine to East Asian business environments, practices, entrepreneurial activity, cross-cultural management, etc. largely started becoming richer from the 1980s, when Japan's economy showed a miracle, Taiwanese

\footnotetext{
${ }^{5}$ Chinese: 汉朝.
} 
and South Korean economies were picking up fast, and the giant Confucian country China awoke from a long sleep.

Incidentally, that is also the time when Vietnam started its Doi Moi (1986), which led to not only FDI inflows that changed the economic situation of the nation, but also steering up the entrepreneurial activities within the largely poor population, which had suffered from poverty and shortage of consumers' goods, and very low living standards, caused by decades of warfare and almost a cessation of private entrepreneurship in large scale.

The Confucian doctrine: What is it? We need to know the facets of Confucianism that may have had strong impacts on private entrepreneurship. Naturally, that knowledge must come from the essence of the doctrine inherited from its origin and long history as a society governing tools by the East Asian feudalist centralized governments.

The Confucianism had its root in the Zhou Dynasty in China (1122-220 B.C.) and was formally established in the Eastern Zhou period, circa 772-221 B.C., by the name of Rú jiā xué shuō, meaning "school of thought by the gentry scholar-officials". ${ }^{6}$ The whole period has been characterized in Chinese literature, especially well known and favorite novels written about society, such as Dong Zhou Lie Guo (in Vietnamese, Dong Chu Liet Quoc), to have been in brutal warfare and as a slave society in transformation to semi-feudal. The society underwent a period of great chaos, extreme violence, and continuous brutal bloodshed in wars among different warring states of China, especially in the Spring-and-Autumn War Period (777-481 B.C.) and the Warring States Period (403-220 B.C.) (Ts'ao 1975). The governing of the society in total chaos became an overwhelming task of the decentralized semi-feudalist government of the Eastern Zhou Dynasty. Until Confucius, the "Rú jiā xué shuō" had still been in the shape of fragmented teachings, offered to the Kings of state mostly in the form of advisory services by the smart, reputable and recognized scholar-officials.

In his times, Confucius coming from a gentry scholar-official family collected different teachings and classics and developed the aforementioned system of values and disseminated them through the advisory services to Dukes of the warring states. Although he had failed to persuade the then political powers (Dukes of states) to use his doctrine over his 11 years of traveling, when

\footnotetext{
${ }^{6}$ In Chinese: 儒家学说
} 
returning to his homeland in Lu State (near Shandong Province, China), he built his own school, teaching his disciples, many of them later became reputable scholar-officials in China's ruling class. Naturally, his disciples and subsequent worshippers of Confucianism continued to have made Confucianism the prevailing and greatly influential system spiritual, political, moral and social values that presided over the Chinese society until the $19^{\text {th }}$ century. Given the influence of Rú jiā xué shuō since Confucius, today the school of thought has been called after his name as Confucianism, making Confucius the father of the system although that is not true.

Was it all gone now? Over two thousand years of history, Confucianism was changed many times by different Confucian scholars. Nonetheless, many major values have been persistent and have continued to have profound impacts on the contemporary East Asian societies, which we would need to explore the influence to private entrepreneurship.

According to historians, Confucianism was introduced into Vietnam during the first and second Chinese colonial periods under the Han Dynasty (both Western and Eastern Han), that is from 110 B.C. to 220 AD. Confucian values came first through local people who studied Confucius' classics and gained some formal title (of very low rank), which was recognized by the Confucian scholar-officials system. In a more systematic way, Confucianism came as a system of guiding moral and social values that were used to set up the society's structure as well as the government, through the introduction by a Chinese-original resident governor, Si Nhiep, who had tendency of installing a social hierarchy and orders, as well as educating local people over organizing life.

Rozman (2002) provides a detailed account of studies on debates over the fate of Confucianism in East Asia, focusing on China, Japan and South Korea. The results presented in this work proved one important understanding: neither Confucianism nor its basic values have been gone. The masses are just largely ignorant of the Confucian nature of their behavior.

Hypothetically, we could explore the following facets of cultural values which showed the presence of Confucian legacy in the contemporary business society in Vietnam. First, the teaching on foundations of the society based on unequal relationships, that Confucius presented in his classics as nature of society. 
Second, the remnants of Confucianism, which strongly remain at micro-level of family and community, the different tiers of the educational system, have helped revive Confucianism as the guiding thought in the local elite groups, business enterprises and society leaders.

Third, the particular process of Vietnam's history could give rise to the Confucianism and its well known particularism, taking into account the similarity of the warfare periods and the degree of sacrifice that society had to yield to the State power and military and financing demands, in the forms of taxes and compulsory fees, when waging long-lasting and, in most cases, brutal wars. We will get back to this point a bit later when discussing historical periods of warfare and chaos.

\subsection{The legendary and profound impacts on entrepreneurship}

The legendary written in Vietnamese can provide us with information and data about the cultural values set by Confucianism. Besides the classic teaching of the Confucian nature, embedded in stories that guide behaviors of the Vietnamese people, the belief has been that doing business, conducting trades and loving profits / money are something not good. Businesspeople, land lords and money-loving figures appeared in Vietnamese legendary stories are mostly bad people, characterized by greed, ugly cultural traits, evil thoughts, source of deteriorating social ethics, and a counter-example of the 'gentlemen' notion.

At fault, in many old stories, which unfortunately became favorite of many generations of readers, several well-known real rebels and bandits who had tendency of violence by robbing assets and gold from the rich and then gave some portion of the robbed value to the poor, have been depicted as heroes in the eyes of the masses, mostly in serfdom. One of the famous examples is recorded in the story of Quan He, by Nguyen (1982). Quan He is the title awarded by the poor to Nguyen Huu Cau, the leader in a major farmer rebellion (1743-1751), in Northern Vietnam under the Le Dynasty (1428-1788).

This cultural reflection through the most popular form of teaching (teachers to students, grandparents to grandchildren, etc.) showed an false favoritism, although seemingly fair, towards the poor, at the price of the business class in the society. This dimension has clearly been a violation of modern knowledge, generally accepted to most of us today, that economic freedom is an essential requisite for continuous growth and development. And this freedom could not be 
obtained without basic guarantee for ownership of private wealth, with which robbers should never be considered an umpire.

The consequence of this kind of teaching through legendary even led to the situation where the masses of the Vietnamese society easily accepted the intervention of the political power by taking from the rich to give to the poor, in the name of "income redistribution". This specific power has indeed close nature to paternalism of Confucianism as we will consider shortly. In line with the well known argument put forward by Milton Friedman in his Free to Choose (1980), we now appreciate the overwhelming challenge of finding a satisfactory method for income distribution in any society. ${ }^{7}$ Clearly, it was naïve to believe this brutal way of redistribution could work in any way. However, that delusion did exist in the mind of the society as another method of income redistribution, so that the public may even find some values pertaining to a possible redistribution alternative in such kind of robbery.

Given the deeply rooted attitude and cultural reflection, we could predict that it is not easy to sweep this kind of bias on businesspeople and entrepreneurs out of the mind of the majority in the society, even if today businesspeople represent a class with high living standards and bringing jobs to many. In fact, the disparity could inadvertently revive the kind of toxic cultural value that the legendary put forward as precursor of social rift. Private entrepreneurship is the course of business by taking risk and creating values for customers' satisfaction with hope for reasonable financial payoffs, thus aiming at private wealth. Nonetheless, in the moral system where the outcome of the risk-taking process could be object for robbery and the wealth may be heralded as associated to those of low dignity, private entrepreneurship was then naturally becoming overwhelming to the majority, and thus not the choice for those in society that did have choices to follow other direction than entrepreneurship.

\subsection{The long-standing Vietnamese social ranking "Sĩ - Nông - Công - Thương”}

Another facet that one could observe directly from the population is the long-standing social ranking that not only classifies strata of the society, but also their corresponding dignity.

\footnotetext{
${ }^{7}$ Friedman writes: "In every society, however it is organized; there is always dissatisfaction with the distribution of income... The farther fields always look greener - so we blame the existing system... In a free market system they [envy and dissatisfaction] are directed at the market."
} 
The Vietnamese old saying of "Sĩ - Nông - Công - Thuoong" is perhaps the kind of social ranking that a normal Vietnamese ever first knows in her/his life. It simply postulates an old feudalist value ranking, equivalent to English meaning of "Gentry scholar/intellectual official - Farmer Craftsman - Trade/Businessman". The reason we have to put forward this in Vietnamese is twofold. First, the postulation is something so familiar that almost all Vietnamese know quite well, both the ranking itself and the meaning of that. Second, its sound in Vietnamese inherited from its original (and identical) Chinese version of "Shì - Nóng - Gōng - Shāng". ${ }^{8}$ Both Vietnamese and Chinese versions share identical meaning of every single word, where Shì had been long placed in the highest ranking of the society, only after the king / emperor, because of the society's hierarchical system based on meritocracy. ${ }^{9}$ The persistence of this cultural facet in the society is quite striking.

Tradesmen, consisting of traders and entrepreneurs, have for long been ranked lowest in terms of dignity in the society. This is opposite to the Western world, where businesspeople together form a fairly high-ranked stratum in the society, mostly with upper class living standards and substantial wealth that could make the masses admire and aspire. The Confucianism we are studying was not the exact one as created by Confucius, because Confucius himself did not stipulated the low dignity of tradesmen. However, due to the interests of political beneficiaries in the feudalist system in East Asia, it is not surprising that altered versions of Confucianism, which had been added and changed by Confucius' disciples and subsequent generations of scholarofficials in elite circle, later looked down on the social values and the dignity of tradesmen in favor of Shi $( \pm)$ as what this facet stipulates today.

In terms of class conflict within the central feudalism in East Asian countries of the time, this lowering of the tradesmen's value and dignity had been done on purpose. Traders and entrepreneurs always find way to retain their economic freedom (albeit only relatively), risk taking characteristics and creativity / innovation. Therefore, they become wise, very experienced and fairly self-reliant. In a system of Confucian values, where loyalty to kings and dukes was

\footnotetext{
${ }^{8}$ The stated social order is: (1) Shì (士) (2) Nóng (农) (3) Gōng (工) (4) Shāng (商). Observing the similarity between the two versions (Vietnamese in Latinate form) and Chinese pinyin tells us nature of culture as a diehard breed, although modern Vietnamese no longer uses Chinese characters.

${ }^{9}$ Shì, when combined with other characters, could constitute different words, such as 博士 [bóshì] a Ph.D degree, or soldier. But the most prominent meaning is 绅士 [shēn shi], that is "the gentry intellectual / scholar circle".
} 
promoted to be a basic and long-lasting one, the growth of tradesmen, their solidarity, the dissemination of the wisdom, altogether could defy the ruling of kings and the elite group of scholar-officials. In brief, tradesmen's wisdom, economic freedom may present some great threat to the power of the feudalist power circle, constituting of kings, dukes and Confucian scholarofficial gentry. A purposely retention of this social ranking was needed by the centralized feudalist governments to uphold the political hierarchy belonging to the aristocratic power circle.

The persistence of this facet has been striking. Although if asked today, the majority of Vietnamese would deny the value of the ranking, but everyone knows that and whenever possible, this ranking could be stated easily as if it is a permanent part of understanding of the society. The well known "face-saving" value of Confucianism has something to deal with right here, where the ranking directly implies the ranking of dignity of a person depending on the social stratum she or he belongs. One would be highly unlikely to embark on such tough and risky road as being an entrepreneur and trader, to reap such a low social value in the eyes of the whole society, except when one has no other choice.

What we do know is without trade, no entrepreneurship could take place since market is the only vehicle for citizens to realize the monetary values of their investment, products, time and energy. Trading activity is in and of itself a most common type of entrepreneurship, which had became a cushion for the Vietnamese economy during turbulent times before, and during, its thriving process starting in the middle of 1990 s.

\subsection{The periods of warfare and chaos}

Since we consider private entrepreneurship a socio-economic process of a country, the socioeconomic environment must be examined to understand why a certain state of development and economic phenomena would likely take place. With respect to entrepreneurship and the particular history of Vietnam, periods of warfare and chaos should be an important knowledge, since they covered a very long period in the country's history, creating particulars and features that would highly likely produce strong impacts on the economic process of the populace.

In the Vietnamese domestic media, the country has frequently been talked of as a society having a long history of approximately 4,000 years of formation and protection of its sovereignty. Nonetheless, serious historians with rectitude usually consider the nation's history covering 
approximately 2,600 years, counting major events and eliminating groundless claim of time due largely to legendary stories. ${ }^{10}$ Roughly speaking, over about three fourth of its 2,600 years history, the country was drowning in different stages of warfare and chaos, which was caused severe consequences for the society and detrimental impacts on the cultural dimensions of that society, especially in terms of business and economic development.

In the second Chinese colonial period (43-554 AD), the Vietnamese society witnessed almost 500 years of war. Before the first Chinese colonial period (603-938), Vietnam enjoyed nearly 60 years of sovereignty, from 544 to 602 . Ironically, in this very short period of sovereignty there were constantly wars between Vietnamese kings with the Chinese officials, and civil wars among kings for power. Therefore, over this 60 -years period, the country was in peace for less than 10 years.

The period of 603-938 AD also witnessed so many brutal wars in Vietnam, with an estimated time length in warfare totaling nearly 100 years. Take one example of the Ly Dynasty in Vietnam's history, ruling the country from 1010 to 1225 . Although this Ly Dynasty is usually considered the peaceful time with good governance by many kings, and prosperous stages of development in the history, that rosy picture painted by generations of historians in reality proves to be only a delusion. During the Ly's administration, the country drowned in continuous wars: 1028-1029 (the Ly family's conflicts); 1038-1048 (war with Nung Tri Cao); 1030-1044 (war with Chiem Thanh); 1075-1078 (war with Tong Dynasty); 1103-1104 (war with Chiem Thanh); 11791225 (Chiem Thanh, border wars, civil wars, and farmers-led rebellions). It is safe to say that the history and characteristics of the Vietnamese society had been formed during long and bloody wars. This particular warfare context was ready to receive the Confucian values, which had also been born as spiritual products of the Chinese brutal civil wars: the Spring-Autumn and Warring States periods. The other feudalist dynasties are even worse off.

In Vietnam, wars are both tools for and consequences of power conflicts or personal ambitious plans by some powerful kings and/or aristocrats. Brutal historical wars in East Asian, in general, and Vietnam, in particular, helped reinforce the political power and maintain the hierarchical

\footnotetext{
${ }^{10}$ According to Tran (1919[2002]), the appropriate period of history for calculation should be from 258 BC to date, or 2267 years, where historical events and sub-periods are documented in some form or could be explained in reasonably logical ways. The period before that, $2879-258 \mathrm{BC}$, history events and legendary description of the established society and state in the land could not be verified by historical evidences. A reasonable estimate of the time length for the Hong Bang period, with 18 kings ruling the country right before $258 \mathrm{BC}$, is about 250-300 years, which makes the history of Vietnam total approximately 2,600 years at maximum.
} 
order of the centralized Confucian feudalist society, in which businesspeople, including both craftsmen and tradesmen, had already been ranked the bottom in terms of respect and dignity.

Furthermore, wars need the finances that the feudalist governments could only obtain from taxes and compulsory fees of various kinds. While Confucian scholar-officials are economic beneficiaries of taxes, and farmers serve to be the main source of personnel for military deployments, besides the stable source of food security in form of agriculture taxes, craftsmen, artisans and traders naturally become main economic agents to be taxed and subjected to heavy financial compulsory contributions and tax obligations arbitrarily stipulated by feudalist governments in emergency warfare periods. The classic teaching of Confucian values suggest that society, especially entrepreneurs consisting of craftsmen and traders, unconditionally accept arbitrary taxation and financially exploiting acts by these historical governments, as a socioeconomic norm, advocated by the doctrine of loyalty to feudalist kings and dukes.

The financial exploitation dragged on over thousands of years in continuous warfare in the Vietnamese history, and the uncertainty of business conducting by the entrepreneurial stratum was exacerbated by the fact that there is almost no chance for this class structure to be changed, since the whole society was deeply embedded in the institutional rigidity of Confucianism, altered to serve the centralized feudalist political beneficiaries.

In chaotic war times and social disorders and anarchy as frequently taking place in the Vietnamese history, entrepreneurship also faced double adversity since entrepreneurial activities are characterized by exploiting opportunities, creating innovations, taking reasonable business risks, and a focus on business target with substantial perseverance. All these require a certain degree of social stability, which could only be attained in peace. Long-lasting and brutal wars in Vietnam destroyed much of the entrepreneurial spirit and energy of the society over its long warfare trajectory, when putting people in the choice of life versus death. The entrepreneurship thus turn out to be a mere tool for earning living without carrying salient features of productive entrepreneurship as a major economic growth driver as described in Schumpeter's and other scholarly works. Suffering ruthless consequence of persistent wars, the last factor of perseverance in pursuing long-term business goals vanished completely, thus strategy has never been a really useful word in the Vietnamese vocabulary. 
The historical wars and chaotic contexts become an additional factor that has made private entrepreneurship in Vietnam, for thousands of years, an undesirable profession and choice.

\subsection{The hidden entrepreneur's aspiration to become non-entrepreneur}

The severe consequences of the socioeconomic and cultural settings that discouraged private entrepreneurship led to the adjustment of entrepreneurial values and also changes of own aspirations by entrepreneurs themselves.

The natural aim of entrepreneurial acts and entrepreneurs is to create value, in parallel with social recognition and the dignity that they deserve, given their risk taking, contributions to national economic prosperity, innovative pursuits, perseverance, etc. In the course of Vietnam's warfare history, this was changed to prioritize personal safety, only reasonable wealth accumulation, and improved social rank and personal dignity; the shift that proves to be logical and understandable following the well known Abraham Maslow's need hierarchy of a person.

Naturally, entrepreneurs did not find the upper value of self-actualization, as defined in the Maslow's hierarchy, in the business pursuits, once the Confucian social hierarchy and pertaining values to each stratum remain. This led to the situation that entrepreneurs, once attaining some desirable level of wealth, had tendency to break with their business root, and to aim at moving to a higher social rank; a change that is relevant in the Confucian doctrine, which was written to educate a "pitiful normal person" to become the noble gentleman $(S \tilde{\imath})$, with noble mission of serving the king. Examples are omnipresent in the Vietnamese legendary stories (Nguyen 1982). In many cases, we encounter examples of a businessman, a landlord, who was for some reason to decide to quit their wealth-making choice was praised as if the person had been civilized or become enlightened and illuminated by the higher values.

One may find this a strange facet of entrepreneurial culture in Vietnam questionable due to the contradicting nature of the phenomenon. However, it is a logical consequence of understandable adjustments to entrepreneurial values, caused by realistic expectations and observation by entrepreneurs. The changes happened not only along the business trajectory of the entrepreneur himself, but also within the business community over the history. One example is the well known proposition within the Vietnamese businesspeople today: To do business, one has to stay lowprofile and relatively quiet (compared to the natural business need of being well advertised and 
strongly branded). With some exception and deviation, the rule is still prevailing and observed by the majority of the business community at present. This rule has clearly been contradicting to the social need of earning esteem, respect and dignity, but it remains valid since it provides some security within the context of prejudice over the notoriously bad image of businesspeople and the presence of potential moral hazards.

\section{Implications of the Confucian Cultural Dimensions on Private Entrepreneurship}

In the previous section, we have gone through some important dimensions that characterize the attitudes of society towards private entrepreneurship. The Confucian values that have profound impacts on the ranking of the society, mentality and determination of the private entrepreneur in the past centralized feudalist society in Vietnam, prevailing until late $19^{\text {th }}$ century after the French put Vietnam under its austerity.

Although the feudalist system was formally abolished in the early $20^{\text {th }}$ century, the Confucian values have been persistent since they are embedded into the society's formal education system, retained in family moral teachings, and preserved in different communities, including today's professional and business.

After the People's Democratic Republic of Vietnam was established by President Ho Chi Minh in the Northern Vietnam (1945) and the defeat of French troops in Dien Bien Phu (1954), the Northern Vietnam was set to follow the centrally planned economic model, similar to China, and then the former Soviet Union. The rise and fall of private entrepreneurship could be examined in this period through socio-political campaigns such as Land Reform (1956-1958), Collectivization of Farms (1959-1970), Rehabilitation of Private Industries and Trades (1964-1975), etc. where the traditional low dignity and rank of private entrepreneurship was recurring. In addition, the socio-economic settings look quite similar to the familiar warfare periods in Vietnam's history, as previously presented in Subsection (3.4).

Once again, after the re-unification of Vietnam, following the collapse of South Vietnam regime, new campaigns were launched to reinforce the Soviet-styled centrally planned model. The reunified Vietnam now entered a new period of sovereignty over its total territories with a low starting point, per capita GDP in range of US\$ 125 to 200, for the period 1975-1982. Instead of nurturing the workforce, productive capacity and capital accumulation within the prevailing 
private entrepreneurship in Saigon by then, the push for nationalizing private physical productive assets, and the rush towards a Soviet centrally planned economy had caused tremendously detrimental effects on the private entrepreneurship of the burgeoning South of Vietnam. Since the change had been overdone, the formal private sector almost vanished over the short period of time from 1978 to 1983, triggering a serious shortage of goods supply and significant lowered living standards. This bias towards a centrally planned model only ended after the well known $6^{\text {th }}$ Communist Party Congress in 1986, when Doi Moi was launched (Pham and Vuong 2009).

In essence, Doi Moi revived the private-sector economy, and hence encouraged private capital investments in legally recognized private entrepreneurial commercial operations. Together with the first FDI Law in 1987, the private entrepreneurship in Vietnam has since comprised of also foreign-invested firms mainly in the form of JVs. Now we have seen the major shift of the contemporary socio-economic context, characterized by: (a) The resurrection of the Vietnamese private sector; (b) The presence of a fledgling market economy and its early fruits; (c) Liberalizing of almost all trade activities, domestic and international; (d) The initializing of international FDI and FPI flows into the economy; and (e) The process of re-integration into the global economy, now on fast lane to the renewed version of globalization.

Clearly, these changes and the new setting have made a positive impact on the Vietnamese private entrepreneurship in many substantial ways. First, there appears to bean increasing trend in favor of monetary values obtained trade and related commercial activities, which partly removed the curse on previous ugly traits of private businessmen in history. Erasing this prejudice is not done overnight, but it is good to see part of that has been gone. Second, a process of gradual changes in the cultural dimensions of the society has been institutionalized by an increasing population of newborn enterprises, in various entrepreneurial forms.

It looks as if new cultural values have been cultivated over the short Doi Moi period of just 20 years, replacing the ancient Confucian values. The question is whether this proposition is true deserves our further discussion. Thus, the next subsections follow.

\subsection{The Confucian values that continue to guide activities of the contemporary society}

Since 1986, Vietnam has been labeled "emerging economy in transition", a process that is usually considered by international economists comparable to China's gradual economic transition. 
Given the broad and deep cultural connections through Confucian values, the relevance of the "culture factor" in facilitating our knowledge acquisition about the why and how of this important trend. Although the central planning economic model was gradually abolished by the Vietnam, its modus operandi proves to be diehard. The paternalistic approach in management continues to be of important use and prevails in various governmental, public and private corporate organizations. While changing economic context and conditions take place everywhere, the cultural facets of a Confucian society like Vietnam change very slowly, with its salient features continuing to be present in every corner of life. Strict Confucian values continue to serve as guiding values for the majority of people, from a simple worker to a business leader or a policy-maker. The well known values in Vietnam that still guide the thinking and behaviors of the masses are: generational orders, hierarchy, paternalism, and loyalty.

These above-mentioned specific values had been reinforced over the long-standing central planning period, with the fact that creation of firms is done by the State, in contrast to entrepreneur's act. The traditional values (and norms and disciplines), which continue to be preserved at the mass level - in families, communities, firms, and the government, serve to have been a "cultural anchor". This anchor is heavy and strong enough to prevent a more radical transition from taking place. Also economic changes have been preferred over political changes, since in a process of radical political changes, the degree of uncertainty increases and longstanding cultural values might no longer be the important factor contributing to the traditional kind of social stability, as they had been before the reform. Naturally, economists frequently find evidences and signals of flinch whenever a major decision in favor of faster pace of reform is to be made. This reality aligns the specific values with the major dimensions of risk avoidance and collectivism, especially the latter since it had for long become the important principle of collective decision making process in the national socio-economic and political life.

Albeit enjoying a lawful status and increasing visibility in society, private entrepreneurs continue to be of lower rank and dignity. In many cases, their act of seeking business opportunities is performed, based on assumptions that benevolence from the government is an essential prerequisite. The private entrepreneur has to do so to their vested interest because of the tendency of the government acting like a parent in the society, in the name of retaining orderly society and stability, a reality that is presented in Friedman (1980, Chapter 3): “... The view that government's role is to serve as an umpire to prevent individuals from coercing one another was 
replaced by the view that government's role is to serve as a parent charged with the duty of coercing some to aid others."

A noteworthy fact is about the public mentality of looking forward to resolve and/or supports from the government, even if the possibility is highly unlikely. We encountered one case during the APEC CEO Summit in Hanoi, late 2006, when participants discussed the removal of disputable state subsidies and assistance, financially or in kind. A Vietnamese firm CEO shared opinion in front of audience that the state would have to provide firms like his with financial supports. Another example is the meltdown of Vietnam Stock Market, during which the VNIndex dropped from nearly 1,200, in early March 2007, to around the level of 300 in March 2009. We met a bunch of money-losing securities investors, who while discussing about the risk and volatility of the stock market kept insisting that the state would intervene to rescue them by using the state coffer money to buy shares, pushing the prices. That turned out a mere impossible scenario, but the belief remained firm albeit groundless. ${ }^{11}$

On the other hand, a typical privately-run entrepreneurial firm operates under the familiar patriarchy of the old father, until his heir (preferably male one) could take over the responsibility, still then under his supervision. Also, at firm level, the connection between Confucian values and family-run entrepreneurship can be observed without ambiguity. Recruitment continues to be done in favor of the Confucian "who you are" value, but not the prevailing market value of "what competence and skills a candidate possesses." In terms of entrepreneurial management practices, through our experience of working with many major successful privately-held firms the first generation of entrepreneurial founders keep relying heavily on trusted family members / relatives, and subordinates who successfully passed the loyalty test or were chosen through ascriptive ties. These values are shared among entrepreneurial firms and state-run firms (including partially privatized ones), but with varying degrees of influence.

\subsection{Relationship-based rent-seeking behavior}

In the theory of entrepreneurship, rent-seeking behavior is a type of activity that seeks to create competitive advantages for a firm over its rivals in the marketplace. The type of rent seeking that

\footnotetext{
${ }^{11}$ This can be seen as opposite to Jefferson's ideal of government (in his first inaugural address 1801): “... a wise and frugal government, which shall restrain men from injuring one another, which shall leave them otherwise free to regulate their own pursuits of industry and improvement."
} 
is going to be discussed here is a typical Confucian value: relationship-based rent-seeking. Relationship is important in development business everywhere, but its color in East Asian cultural setting is quite different from the West. Relationship in Vietnam (quan he) and China (guān xì) refer to many social aspects between individuals, and is rarely limited within the scope of professional works. ${ }^{12}$

Relationships are important in human societies where interactions between individuals get complicated over the time, due to the size and complexity of socio-economic situation. But they have a special meaning in the Confucian system of value, because Confucianism advocates unequal relationships between individuals in a typical Confucian society and imposes moral and cultural norms for guiding behaviors of the society. Napier and Thomas (2004) present some relevant analysis and practical evidence on this aspect of the Vietnamese business cultural setting, such as the existence of a kind of labor aristocracy, consisting of reliable and skilled workers usually Party member - with better pay, some additional privileges who act as bridge between manager and labor (pp.21). However they have not discussed the Confucian roots of issues observed in the economy.

A typical example of that is the so-called "relationship-based bank loan", a well known phenomenon that receives much attention of economists when studying the contemporary economy of Vietnam. ${ }^{13}$ Vietnam's private entrepreneurs, mostly operating small- and mediumsized enterprises (SME), constantly face the shortage of capital, both equity and debt. Over $90 \%$ of domestic SMEs could be classified as belonging to "nano-cap" category, in terms of asset size.

Debt financing is thus perhaps the single most important financing option, of which bank loans have, for many reasons, been far more influential than other type of financing, such as financial leasing or corporate bonds (Vuong 1997a, 1997b, Pham and Vuong 2009).

Thus, relationship with banks is not only matter of financing entrepreneurs' cash need and pursuit of investment, but also the wish of maintaining business advantage in terms of capital sufficiency. Whenever possible, entrepreneurs seek to improve access to bank's credits. Typically, the relationship between a bank and an entrepreneur is unequal, with the general attitude being the

12 In Chinese: 关系. The Chinese 'guānxì' and Vietnamese 'quan he' sounds very similar, bearing the same meaning of two parts, when combined together mean "System of concerns and issues to be addressed (perhaps jointly)".

${ }^{13}$ Data are provided in details by Pham and Vuong (2009). 
borrowing entrepreneur "asking for funds". Again, this is very much in line with the cultural face of a banker knowing "who the entrepreneur is" rather than "what capacity he/she possesses". Even when there is intervention by the government, such as the stimulus package with $4 \%$ interest rate subsidy by the state fiscal budget, starting from February 2009 till the year-end, the situation does not change much. According the Association of SMEs, only $10 \%$ of entrepreneurs could access this debt finance, not to say that usually their credit limit is very low. Larger and well-established firms, including SOEs and partially privatized SOEs, clearly enjoy the fast expansion of credit scale in this program, due largely to long-standing and close relationships with banks. Thus, small entrepreneurial firms, with thin equity base, face not only higher cost of funds but also limited access to that costly debt.

In all kinds of trust-based transactions, bank credit transaction is perhaps the most apparent manifestation of the Confucian value of social relationship. Credit in both Chinese and Vietnam means "the use of trust". Trust in Confucian society means a relationship in which one could put the work in the hand of someone that he/she knows and is confident of. Additional aspect of it could be reciprocity in making transactions happen, such as asking for/granting bank loans. It has been not uncommon that many bankers when having 'good' relationship with entrepreneurial borrower could on behalf of the borrowers prepare borrowing documents. Both sides believe this is part of the care-taking element in their trust-based relationship, a traditional Confucian value, partly reflecting the factor of benevolence that had been highly advocated in Confucianism. This relationships have tendency of being reinforced over time and history of transaction, where superior relationship-based economic rent is obtained (such as in the time of credit-crunch, liquidity crisis or in advent of capital-intensive highly profitable opportunity) by the borrower and shared between two sides by reciprocity of benefits.

Given the fact that the Confucian value is behind this kind of relationship-based rent seeking, and this traditional value is omnipresent in the Vietnamese contemporary society, we could predict, without losing generality, that there exist various kinds of relationship-based economic rents, of which banking transaction is only one typical manifestation. The implication of this on the local entrepreneurs is twofold. First, economic rents guide the behavior of entrepreneurs in seeking improved profits and financial safety net. Second, the differences caused by the rents between established firms and entrepreneurial manifest the overwhelming challenge faced by the private entrepreneurs. The general trend is this leads to an increasing level of cost over the society for developing and maintaining relationships, causing unavoidable new friction. 


\subsection{On the business education in Vietnam}

In this last discussion of implications of the Confucian cultural values, we would like to point to the educational system, with respect to the specific area of business education. Business education had not been existent in Vietnam's education system until early 1990s. A consequence of that is still today one could easily observe the dearth of business studies of substantial quality in Vietnam.

Although there have been many international business education programs operating in Vietnam, producing increasing crops of business graduates, including an increasing number of MBAs, still the quality is questionable. The question of business education quality has nothing to do with the program of study itself or the students' capability of acquiring modern business knowledge, mostly international and relevant to the current trend of Vietnam's market economy. Vuong (2007) attributes the problem to lack of appropriate cultural values, for MBA and undergraduate business education program of study requires participants to have right determination and appropriate would-outlook. These factors are far more important than technical and other skills obtained from business education.

To see why inappropriate world-outlook can be detrimental to business graduate quality, let's take MBA training as an example. The Confucian system of outlook promotes the "good face" value. The value remains today. MBA is an academic degree and the "graduation" itself has "good face" element in it. The majority of MBA share the thought that the degree itself has equal value to the knowledge, skills obtained from the training. Obtaining the degree, a level above bachelor's, is a guarantee for higher rank in the education hierarchy. This world-outlook helps reduce the MBA quality to striving to pass exams so that participants could be granted the degree.

There have been very few business-oriented books written in Vietnamese by Vietnamese. Almost all books are translations of world known books. Naturally, one would have a question: Is it true that Vietnam has no good authors. On surface and in reality, the question is: Almost correct. Bearing the "good face" value in mind and blood vein, business schools" professors themselves act as if they are on the pinnacle of the educational system. Thus, academic works such as scholarly papers, academic books and other intellectual activities are not part of the value system. In other words, the business education system is very much similar to the ancient examination 
system that used to serve the scholar-official designating process in the old Confucian society. By this way, business education does not help much in the process of generating a new wave of entrepreneurs or reinforcing the entrepreneurial spirits, since the professors simply do not share or have that value.

\section{Final Remark}

This essay has gone over a number of important discussions. In this short final remark we now emphasize the factors that may trigger changes or serve as catalysts for faster pace of cultural adaptation in the changing business environment of Vietnam. There would likely be a stronger impact of WTO and globalization in the Vietnamese economy, thus affecting the private entrepreneurship through new opportunities and new impetus for changes.

Economic freedom for entrepreneurs would likely become an important factor that helps support both entrepreneurial choice by many people and the formation of thriving entrepreneurs' stratum in the society. Although the long-standing traditional cultural values and related facets are expected to be present in families, community and society, at the mass level, but the improved business environment and increased number of entrepreneurs and their colleagues would force these traditional values to change and adapt to the new setting, which we hope to be much more business-oriented. 


\section{BIBLIOGRAPHY}

Ted Baker, Eric Gedajlovic, and Michael Lubatkin (2005) "A Framework for Comparing Entrepreneurship Processes across Nations," Journal of International Business Studies, Vol. 36, No. 5, pp. 492-504.

André Farber, Tran Tri Dung, Nguyen Huu Tu, and Quan-Hoang Vuong (2008) "The Financial Storms in Vietnam's Transition Economy: A Reasoning on the 1991-2008 Period," Working Papers CEB, No. 08-023.RS, SBS-EM (Université Libre de Bruxelles), http://EconPapers.repec.org/RePEc:sol:wpaper:08-023

Milton Friedman and Rose Friedman (1980) Free to Choose - A Personal Statement, Harcourt Brace Jovanovich, NY 10017.

Sidney M. Greenfield and Arnold Strickon (1981) "A New Paradigm for the Study of Entrepreneurship and Social Changes," Economic Development and Cultural Changes, Vol. 29, No. 3, pp. 467-499.

Eric L. Jones (2006) Cultures Merging, Princeton University Press, Princeton, NJ 08540.

G. T. Lumpkin and Gregory G. Dess (1996) "Clarifying the Entrepreneurial Orientation Construct and Linking It to Performance," The Academy of Management Review, Vol. 21, No. 1, pp. 135-172.

John McMillan and Christopher Woodruff (2002) "The Central Role of Entrepreneurs in Transition Economies," Journal of Economic Perspectives, Vol. 16, No. 3, pp. 153-170.

Nancy K. Napier and David C. Thomas (2004) Managing relationships in transition economies, Praeger Publishers, Westport, CT 06881.

Dong-Chi Nguyen (1982) Kho Tang Truyen Co Tich Viet Nam (in Vietnamese; English title: The Vietnamese Legendary Stories), Nha Xuat Ban Van Hoc.

Minh Chinh Pham and Quan-Hoang Vuong (2009) Kinh te Viet Nam - Thang Tram va Dot Pha (in Vietnamese; English title: Vietnam's Economy - The Rise and Fall, and the Shifts), National Political Publisher, Hanoi, Vietnam. http://empirics.net/FileUpload/download/books/empirics.net_KTVN.pdf

Don Robotham (2005) Culture, Society and Economy, SAGE Publications, Thousand Oaks, CA 91320.

Per Ronnås (1992) Employment Generation through Private Entrepreneurship in Vietnam, ILO Publications.

Gilbert Rozman (2002) "Can Confucianism Survive in an Age of Universalism and Globalization?" Pacific Affairs, Vol. 75, No. 1, pp. 11-37.

M. Joseph Sirgy (1986) “A Quality-of-Life Theory Derived from Maslow’s Development Perspective: Quality is related to Progressive Satisfaction of a Hierarchy of Needs, Lower Order and Higher," American Journal of Economics and Sociology, Vol. 45, No. 3, pp. 329-342. 
Howard H. Stevenson and J. Carlo Jarillo (1990) “A Paradigm of Entrepreneurship:

Entrepreneurial Management," Strategic Management Journal (Special Issue: Corporate

Entrepreneurship), Vol. 11, pp. 17-27.

John M. Stopford and Charles W. F. Baden-Fuller (1994) "Creating Corporate Entrepreneurship," Strategic Management Journal, Vol. 15, No. 7, pp. 521-536.

Trong Kim Tran (1919[2002]) Viet Nam Su Luoc (越南史略) (in Vietnamese; English title: A Brief History of Vietnam), Nha Xuat Ban Van Hoa Thong Tin, Hanoi.

Ignasius J.H. Ts'ao (1975) "Confucius in the Middle of the New Cultural Revolution Today," Studies in Soviet Thoughts, Vol. 15, No. 1, pp. 1-33.

Quan-Hoang Vuong (1997a) “A Question of Leverage," Vietnam Investment Review, March 2430, 1997, pp. 13.

Quan-Hoang Vuong (1997b) “The Leasing Alternative," Vietnam Business Journal, Vol. 5, No. 3, pp. 26.

Quan-Hoang Vuong (2007) Van Minh Lam Giau \& Nguon Goc Cua Cai (in Vietnamese; English title: The Civilization of Business \& the Origin of Wealth), National Political Publisher, Hanoi, Vietnam. http://empirics.net/FileUpload/download/books/Empirics.net_VMLGa.pdf 